\title{
The Body and the Sacred in the Digital Age: Thoughts on Posthuman Sexuality
}

\author{
Brett Lunceford
}

\begin{abstract}
Considerable scholarly discussion has been given to the idea that we are moving toward a state of "posthumanism." In this essay, I examine some possible implications of a posthuman existence, specifically as it relates to that most basic of human needs - sexuality. More specifically, I am interested in exploring the spiritual aspects of sexuality to see what is lost and what is gained in technologically mediated forms of sexuality. To that end, I consider the interplay between sexual behaviour and our conceptions of the sacred, how technologies are changing our views of - and realities concerning-our bodies, and the potential for a sacred posthuman sexuality.
\end{abstract}

Keywords: embodiment, mediation, posthuman, sacred, transhuman.

Considerable scholarly discussion has been given to the idea that we are moving toward a state of "posthumanism." Elaine Graham writes:

New digital and biogenetic technologies-in the shape of media such as virtual reality, artificial intelligence, genetic modification and technological prosthetics-signal a 'posthuman' future in which the boundaries between humanity, technology and nature have become ever more malleable. ${ }^{1}$

\section{Leopoldina Fortunati makes a similar argument:}

In post-modern society, the social system of differences developed in the modern age is being completely restructured. Many differences, even between men and women, or more specifically, between the world of production and reproduction, have disappeared, or are at least less clear cut. There is a tendency at the social level to fusion, to the formation of hybrids, to the development of similarity. Many of these differences are artificial constructions, the result of historical, social, and cultural determinations. $^{2}$

1. Elaine Graham, "Cyborgs or Goddesses? Becoming Divine in a Cyberfeminist Age," Information Communication \& Society 2.4 (1999), p. 419.

2. Leopoldina Fortunati, "The Human Body: Natural and Artificial Technology," in James Everett Katz (ed.), Machines That Become Us: The Social Context of Personal Communication Technology (New Brunswick, NJ: Transaction Publishers, 2003), p. 79. 
If we are evolving toward a state of technologically induced hybridity, then what of the body? Despite post-modern scholars' claims that gender and sexuality are socially constructed, the body still matters and how we choose to use our bodies has changed little since the beginning of recorded history. People still choose to do such things as eat, sleep, engage in sex, move around, examine our surroundings, and no amount of exultation in the cyborg life will alter these desires because they are biological imperatives.

Nicholas Negroponte argues that we are all becoming digital: "It is here. It is now. It is almost genetic in its nature, in that each generation will become more digital than the preceding one." ${ }^{3}$ Negroponte is not making a biological claim; rather he makes a cultural claim, as does Fortunati. If Negroponte and Fortunati are correct, how would this affect conceptions of the body? In other words, what happens when one has a digital soul in an analog body? I suggest that despite trends toward digitality, even the most technological societies are far from leaving the body behind. One reason for this is because the human experience is bound up in the experience of the sacred and experience of the sacred is linked to the practices of the body.

"What is love?" is a question that has plagued philosophers and feeling individuals since time immemorial. "What is sex?" is one that, although no less problematic to define in ontological terms, is a question to which one generally has an answer. But in an age of phone sex, cybersex, and even the possibility of teledildonics, the question of how one defines sex has become more difficult to authoritatively answer. The cliché that the brain is the most important sexual organ overlooks the fact that people have many other erogenous zones that they are just as interested, if not more interested, in having someone get to know. In this article, I examine some possible implications of a posthuman existence, specifically as it relates to that most basic of human needs-sexuality. Jane Caputi notes that "sexuality.... is the indelible mark of the sacred on our bodies, an endlessly evocative epigram written on the flesh, to both delight and puzzle us so that we might know god/dess." ${ }^{4}$ If sexuality is bound up in the flesh and the spirit, the posthuman impulse to transcend the body has spiritual implications. The remainder of this article explores the spiritual aspect of sexuality to see what is lost and what is gained in technologically mediated forms of sexuality.

Before I begin, I wish to explain that when I say "soul," I do not have a specific religious connotation in mind. Although there are some

3. Nicholas Negroponte, Being Digital (New York: Knopf, 1995), p. 231.

4. Jane Caputi, "The Naked Goddess: Pornography and the Sacred," Theology \& Sexuality 9.1 (2002), p. 182. 
who believe that humans are simply carbon-based organisms that differ from other animate entities only in terms of complexity, I suggest that far more view themselves as having some kind of essence irreducible to the chemical reactions that take place in one's brain. One may refer to this essence as the soul, their emotions, or anything else he or she chooses, but for the purposes of this article I will refer to that which one considers apart from, but integrated with, the body as the soul.

\section{Sexuality and the Sacred}

Conceptions of the sacred are a fundamental element of the human experience. Jean-Paul Sartre suggests that "the best way to conceive of the fundamental project of human reality is to say that man is the being whose project is to be God... To be man means to reach toward being God." 5 In the biblical account of Adam and Eve in the Garden of Eden, Adam and Eve were cast out not only because of their disobedience, but because they had become more like God:

And the LORD God said, Behold, the man is become as one of us, to know good and evil: and now, lest he put forth his hand, and take also of the tree of life, and eat, and live for ever: Therefore the LORD God sent him forth from the garden of Eden, to till the ground from whence he was taken. So he drove out the man; and he placed at the east of the garden of Eden Cherubims, and a flaming sword which turned every way, to keep the way of the tree of life. ${ }^{6}$

This ability to become like God was what convinced Eve to partake of the forbidden fruit:

And the serpent said unto the woman, Ye shall not surely die: For God doth know that in the day ye eat thereof, then your eyes shall be opened, and ye shall be as gods, knowing good and evil. And when the woman saw that the tree was good for food, and that it was pleasant to the eyes, and a tree to be desired to make one wise, she took of the fruit thereof, and did eat, and gave also unto her husband with her; and he did eat. ${ }^{7}$

For the Judeo-Christian tradition, the origin of man and woman begins with a willingness to defy God in an attempt to become more godlike. Some have suggested that the forbidden fruit was actually sexual intercourse. Although many, including myself, reject that notion, the fact that such a tradition would become commonplace demonstrates how sexuality and the fall of Adam and Eve are bound together in our collective psyche.

5. Jean-Paul Sartre, Existentialism and Human Emotions (Secaucus, NJ: Citadel Press, 1957), p. 63

6. Gen. 3.22-24.

7. Gen. 3.4-6. 
A core function of religion is to regulate and control sexuality and the control of sexuality is not only a moral imperative but a way to maintain control of followers. For example, in the Old Testament, before they were to enter the promised land, the Lord commands the children of Israel to cut down the groves (asherah, or pole or tree representing a fertility goddess) of the Canaanites. ${ }^{8}$ One probable reason for this is because these groves were sites of fertility rites - for the Canaanites, these rites were sacred sexual practices. It is also likely that such rites were rather inviting to the newly-arrived Israelites. Julia Kristeva notes that "while the neighboring nations (Hittites as well as Semites) carried out sexual rites in sacred grove or temple...the Jews alone had no sexual rites." ${ }^{\prime 9}$ Perhaps it is not without significance that when the Lord chastises the children of Israel for abandoning him and following after other gods, he states that they had gone "whoring after" other gods. ${ }^{10}$

In answer to her own question, "Why are so many spiritual movements obsessed with eradicating the sexual?" Susie Bright states, "Repression of the body is prerequisite to subordination." 11 One reason for this may be because the body and the intellect are connected and, in cases of sexuality, the body may completely overcome the intellect and the spirit. Augustine writes of sexual excitement:

Such lust does not merely invade the whole body and outward members;
it takes such complete and passionate possession of the whole man, both
physically and emotionally, that what results is the keenest of all pleas-
ures on the level of sensation; and, at the crisis of excitement, it practically
paralyzes all power of deliberate thought.

But such a state of ecstasy may be seen as a spiritual experience brought on by the pleasures of the flesh. In some Biblical passages, "to know" one's wife is to have sexual intercourse with her. ${ }^{13}$ This seems an apt metaphor; sex involves a literal knowing of another's body-one can sense, taste, smell, hear, and see what is taking place in the body of another. This is a consequence of the nature of sexual union and applies equally to all forms of sexual encounters. Antonio Rosmini writes, "I think that one soul may feel another soul or spirit by means of the body

8. See Exod. 34.13; Deut. 7.5.

9. Julia Kristeva, Tales of Love (trans. Leon S. Roudiez; New York: Columbia University Press, 1987), p. 95.

10. See Exod. 34.15-16; Lev. 20.5-6, 17.7; Num. 15.39; Deut. 31.16; Judg. 2.17, 8.27, 8.33; 1 Chron. 5.25; Ezek. 6.9, 23.30.

11. Susie Bright, Full Exposure: Opening Up to Sexual Creativity and Erotic Expression (San Francisco: HarperSanFrancisco, 1999), p. 120.

12. Augustine, The City of God (trans. Gerald G. Walsh, et al.; Garden City, NY: Image Books, 1958), p. 315.

13. See Gen. 4.1, 17, 25; 1 Sam. 1.19-20. 
and in the body... In love and friendship, two souls seem to feel each other and communicate with each other by affection and the union of their bodies."14 The body and soul are intertwined and as physical connection with one may lead to connection with the other.

In the Symposium, Aristophanes relates a creation myth that describes a time when there were three genders - men, women, and hermaphrodites that were men and women who were joined together as one. ${ }^{15}$ Because the hermaphrodites had become too powerful, Zeus decided to split them in half to make them half as powerful and twice as plentiful. However, they yearned for the other such that they wanted nothing more than to be with each other and began to die because of "hunger and general inertia."16 To keep the race from dying out, Zeus moved their genitalia to the front rather than where they previously existed on the outside:

He moved their members round to the front and made them propagate among themselves, the male begetting upon the female-the idea being that if, in all these clippings and claspings, a man should chance upon a woman, conception would take place and the race would be continued, while if man should conjugate with man, he might at least obtain such satisfaction as would allow him to turn his attention and energies to the everyday affairs of life. So you see, gentlemen, how far back we can trace our innate love for one another, and how this love is always trying to reintegrate our former nature, to make two into one, and to bridge the gulf between one human being and another. And so, gentlemen, we are all like pieces of the coins that children break in half for keepsakes... and each of us is forever seeking the half that will tally with himself. ${ }^{17}$

Aristophanes' account may seem like a far-fetched creation myth but there are many today who believe in the idea of a "soulmate," an individual with whom he or she is destined to be. To some extent, this may be a kind of post hoc argument that justifies the decision to be with a particular person -"I am with this person; I was meant to be with this person." However, conceptions of love are often laced with allusions to the supernatural and rightfully so-few experiences occupy the limnal space between reality and fantasy so well as that of being in love.

Aristophanes' description of the desire to "bridge the gulf between one human being and another" also persists. Maurice Merleau-Ponty argues:

14. Antonio Rosmini, Development of the Human Soul (trans. Denis Cleary and Terence Watson; Durham, UK: Rosmini House, 1999), p. 115.

15. Plato, "Symposium," in Edith Hamilton and Huntington Cairns (eds.), The Collected Dialogues of Plato, Including the Letters (Princeton, NJ: Princeton University Press, 1961), 189e-193d, pp. 542-46.

16. Plato, "Symposium," 191b, p. 543-44.

17. Plato, "Symposium," 191c-191e, p. 544. 
The intensity of sexual pleasure would not be sufficient to explain the place occupied by sexuality in human life or, for example, the phenomenon of eroticism, if sexual experience were not, as it were, an opportunity, vouchsafed to all and always available, of acquainting oneself with the human lot in its most general aspects of autonomy and dependence. ${ }^{18}$

Sexuality is such a part of human nature that despite academic assertions that gender is socially constructed, ${ }^{19}$ there seems to be something about sexuality that transcends culture. The point at which the sexual transcends the cultural is where the sexual becomes the spiritual.

Aristophanes' explanation of the origin of the sexes is also reminiscent of the biblical imperative: "Therefore shall a man leave his father and his mother, and shall cleave unto his wife: and they shall be one flesh." ${ }^{20}$ This is reinforced in the New Testament: "For this cause shall a man leave father and mother, and shall cleave to his wife: and they twain shall be one flesh? Wherefore they are no more twain, but one flesh. What therefore God hath joined together, let not man put asunder."21

Combining sexuality and spirituality is not exclusive to the JudeoChristian tradition. For example, temple prostitution has a long tradition reaching back to ancient Sumeria, Greece, India, and Babylon. Georg Feuerstein notes:

Wherever there were temples and a priesthood, prostitution was also to be found. We need not adduce cynical motives for this association, for, as we have seen, sexuality and religion have been in close kinship since time immemorial, long before temples were erected and priests were appointed (or appointed themselves) as messengers of the Divine. ${ }^{22}$

Paul Chambers writes that "virtually every temple, including the Judaic ones, is recorded as having prostitutes or sexually available women attached to it... Most temple prostitutes were regarded very highly, since it was considered that they were effectively worshiping the god or the goddess of the temple with their bodies." ${ }^{23}$ In some cases, the participants actually represented the goddesses. The symbolic act of becoming the gods and goddesses through sexual union

18. Maurice Merleau-Ponty, Phenomenology of Perception (trans. Colin Smith; London: Routledge \& Kegan Paul, 1962), p. 167.

19. See Judith Butler, Gender Trouble: Feminism and the Subversion of Identity (New York: Routledge, 1990); Judith Butler, Bodies That Matter: On the Discursive Limits of "Sex" (New York: Routledge, 1993).

20. Gen. 2.24.

21. Mt. 19.5-6. See also Mk 10.8; 1 Cor. 6.16; Eph. 5.31.

22. Georg Feuerstein, Sacred Sexuality: Living the Vision of the Erotic Spirit (Los Angeles: Jeremy P. Tarcher, 1992), p. 71.

23. Paul Chambers, Sex and the Paranormal: Human Sexual Encounters with the Supernatural (London: Vega, 2003), p. 68. 
can also be had through ritualistic sex practices. Feuerstein states that in some forms of Indian Tantric rituals, participants participate in ritualistic sex and stand in for the gods Shiva and Shakti. ${ }^{24}$ Such practices have been taken up and adapted by modern authors and practitioners as well. ${ }^{25}$

In short, the notion of sexuality is wrapped up in the sacred. Perhaps this is partially because sexuality remains, in large measure, a mystery that is constantly unfolding before us. Although researchers have made large strides in understanding the physiological processes of sexual behaviour, the emotional and spiritual elements of sexuality elude us, possibly because science is ill equipped to measure changes in the soul. Thus, the study of sexuality is not only a study of the body, but also of the soul. But the soul and the body are not completely separate; they are intertwined, and changes to the body may also influence the soul.

\section{Sex and the Technological Body}

Ollivier Dyens writes: "The virtual being is real, but of a different kind of real, one that is both organic and technological. This being is a cultural animal, a nonorganic being. The cultural being is in a new stage of evolution." 26 Thus, one cannot simply consider one's virtual presence imaginary, something that is not really there. Monica Whitty rightly argues that "although the physical bodies are not present in cyberspace, the body still does matter." 27 The link between the body and the virtual presence makes cyberspace something that is like reality but not quite. Concerning cybersex, Julian Dibbell writes:

Amid flurries of even the most cursory described caresses, sighs, and penetrations, the glands do engage, and often as throbbingly as they would in a real-life assignation-sometimes even more so, given the combined power of anonymity and textual suggestiveness to unshackle deep seated fantasies. And if the virtual setting and the interplayer vibe are right, who knows? The heart may engage as well, stirring up passions as strong as many that bind lovers who observe the formality of trysting in the flesh. ${ }^{28}$

24. Feuerstein, Sacred Sexuality, ch. 10.

25. See Margot Anand, The Art of Sexual Magic (New York: G. P. Putnam's Sons, 1995).

26. Ollivier Dyens, Metal and Flesh: The Evolution of Man: Technology Takes Over (Cambridge, MA: MIT Press, 2001), p. 33.

27. Monica Therese Whitty, "Cyber-Flirting: Playing at Love on the Internet," Theory \& Psychology 13.3 (2003), p. 345.

28. Julian Dibbell, "A Rape in Cyberspace," in Victor J. Vitanza (ed.), Cyberreader (Boston: Allyn and Bacon, 1999), pp. 458-59. 
Where is the person who is having cybersex and with what is he or she penetrating and/or penetrated with? Juan-David Nasio suggests that "language is an organ, not in the instrumental sense of an efficacious tool-as Chomsky believes - but an organ that prolongs and extends the body." ${ }^{29}$ In cybersex, then, the body is excited by the use of language rather than by the use of the body. But this can take place in the presence of another, especially for those who enjoy coprolalia, or "talking dirty," when engaging in sexual activity, thus it may be a misnomer to say that cybersex is even sex. That it may be sexual is not in question, but to put it on the same level of magnitude of intimacy as physical sexual activity seems unreasonable. But the notion of the media as extensions of the body, which has long been championed by Marshall McLuhan, is worth considering. McLuhan noted that the "outering or extension of our bodies and senses in a 'new invention' compels the whole of our bodies to shift into new positions in order to maintain equilibrium. A new 'closure' is effected in all our organs and senses, both private and public, by any new invention." ${ }^{30}$ But Graham argues that "technologies are not so much an extension or appendage to the human body, but are incorporated, assimilated into its very structures. The contours of human bodies are redrawn: they no longer end at the skin." 31

In some ways, technologies beyond language are able to literally act as extensions of the flesh, even in the realm of sexual intercourse. For example, Sinulator offers a product that allows the users to literally use technologies that act as an extension of the penis and the vagina. ${ }^{32}$ In this configuration of cybersex, the man inserts his penis into a sleeve that resembles a synthetic vagina. On the other end of the circuit is a woman (or man) who inserts a vibrator into her vagina (or any other orifice). The speed of vibration and motion are determined by the male partner's speed of thrusting. This is much closer to sexual intercourse than simply typing erotic text directed at another on a keyboard. It also blurs the lines between the real and the virtual. If one were to send an erotic letter to another, and it were found out by his or her spouse, the spouse may suspect that physical interactions had also taken place. However,

29. Juan-David Nasio, The Book of Love and Pain: Thinking at the Limit with Freud and Lacan (trans. David Pettigrew and François Raffoul; Albany: State University of New York Press, 2004), pp. 106-107.

30. Marshall McLuhan, Understanding Media: The Extensions of Man (Cambridge, MA: MIT Press, 1st MIT Press edn, 1994), p. 252.

31. Elaine L. Graham, Representations of the Post/Human: Monsters, Aliens, and Others in Popular Culture (New Brunswick, NJ: Rutgers University Press, 2002), p. 8.

32. "Sinulate Entertainment Home Page." Sinulate Entertainment, http://www. sinulate.com. 
it would be difficult to prove and if the offending party could convince the spouse that nothing had yet happened, the spouse may be content to believe that the problem had been nipped in the bud before anything "real" had taken place, albeit with a diminished sense of trust in the offending party. However, consider the case if the spouse were to walk in on the other in flagrante delicto, and see the other party on the screen actively participating in the act. Despite the absence of the other party, it is difficult to claim that nothing was actually taking place between the two. It is true that no bodily fluids were exchanged and that each penetrated or was penetrated by only synthetic flesh, but still-something would have taken place.

Perhaps McLuhan would be comfortable arguing that such teledildonics are extensions of the genitalia, but there still seems to be something missing from the equation because it is difficult to say whether or not it is exactly the same as adultery. Of course, the offending spouse would not have been faithful in the mental or emotional sense, but what of the physical sense? And how would this be different from someone masturbating to a pornographic magazine? Perhaps the key element here is what it means to each person involved directly or indirectly in the act and the fact that there are at least two active participants in the act and three in the relationship. The object of desire in pornography is not an active participant in one's masturbatory fantasies (at least not at the same time) and although the viewer may feel some psychological connection to the person in the image, the person in the image feels little for the viewer. Teledildonics may be more than simply an extension of one's genitalia; rather, it may serve as an extension of one's active participation. A session of phone sex or text-based cybersex allows for synchronous erotic expression and participation but does not allow for being in each other's presence. Teledildonics partially overcomes this limitation in allowing each participant to alter the other's physical experience in ways that simulate presence.

Teledildonics may be a symptom of a larger shift in society. Dyens argues that "machines coevolve with us; our respective existences are completely tied to each other. To reflect upon technological culture is thus not simply to think about the impact of technologies on our world, but also to examine the emergence of new strata of reality, where living beings, phenomena, and machines become entangled." ${ }^{33}$ But as humans and machine march forward to their shared destiny, it is sometimes difficult to recognize what is being left behind. For example, Fortunati argues that because of our reliance on ICTs, "beyond the remaining

33. Dyens, Metal and Flesh, p. 11.

(c) Equinox Publishing Ltd 2009. 
old poverty, which exists even in the industrialized nations, the new poverty that affects everybody is a poverty of first-hand reality." ${ }^{34}$ As relationships become increasingly mediated, especially in the realm of sexual intimacy, conceptions of what it means to be in an intimate relationship may shift.

Changes in conceptions of sexuality are constantly evolving. Lewis Mumford describes sexuality in the "paleotechnic phase" of the industrial era: "This starvation of the senses, this restriction and depletion of the physical body, created a race of invalids: people who knew only partial health, partial physical strength, partial sexual potency." ${ }^{35} \mathrm{He}$ laments that "The secrets of stimulation and sexual pleasure were confined to the specialists in the brothels, and garbled knowledge about the possibilities of intercourse were conveyed by well-meaning amateurs or by quacks whose books on sexology acted as an additional bait, frequently, for their patent medicines." ${ }^{\prime 36}$ In an era of one night stands and cybersex, this could just as easily describe modern sexual practice. We have pharmaceuticals crafted to remedy sexual dysfunctions of every kind-except those of the soul.

Mumford writes that in the twentieth century sexual expression became more public and commoditized, but "instead of enriching the erotic life and providing deep organic satisfactions, these compensatory measures tended to keep sex at a constant pitch of stimulation and ultimately of irritation." ${ }^{37}$ In other words, for Mumford, more sexual expression is not necessarily a benefit to society in itself. Mumford provides a way from this hyperstimulation:

Most of the sexual compensations were little above the level of abject fantasy; whereas when sex is accepted as an important mode of life, lovers reject these weak and secondary substitutes for it, and devote their minds and energies to courtship and expression themselves: necessary steps to those enlargements and enrichments and sublimations of sex that alike maintain the species and energize the entire cultural heritage. $^{38}$

It seems that Mumford is advocating a more connected form of sexuality than that proposed by the purveyors of tawdry strip joints or pornography. In short, it seems that he is advocating the intermingling of sexual expression with love as both a means to an end-propagate the human race-as well as a way to reach a higher plane of intimacy with

34. Fortunati, "The Human Body," p. 75.

35. Lewis Mumford, Technics and Civilization (New York: Harcourt Brace \& Company, 1963), p. 108.

36. Mumford, Technics and Civilization, p. 180.

37. Mumford, Technics and Civilization, pp. 299-300.

38. Mumford, Technics and Civilization, p. 300. 
another person. This seems consistent with Abraham Maslow's description of sexuality in self-actualizing people:

We cannot go so far as some who say that any person who is capable of having sexual pleasure where there is no love must be a sick man. But we can certainly go in this direction. It is certainly fair to say that selfactualizing men and women tend on the whole not to seek sex for its own sake or to be satisfied with it alone when it comes. ${ }^{39}$

Sexual behaviour can never be completely relegated to the realm of the socially constructed because these norms are rooted in biological necessity. Dyens argues that our standards of beauty are based on physical cues that display good health, a strong immune system, and sexual potency. "This relationship between the 'effectiveness' of a body and others' lust for it is an example of the biological reality. We are sexually attracted to what we are biologically at a specific moment in time. Standards of beauty are controlled by organic needs." 40 However, he also notes that we are shifting to a form of culturally defined beauty: "We are attracted to Hollywood stars not only because of their biological beauty (i.e. organic effectiveness) but also because of their cultural productivity. What we seek today are bodies sculpted by culture. A Hollywood star, male or female, who has had cosmetic surgery, is a cultural being, and this is what seduces us." ${ }^{41}$ N. Katherine Hayles echoes this point:

Experiences of embodiment, far from existing apart from culture, are always already imbricated within it. Yet because embodiment is individually articulated, there is also at least an incipient tension between it and hegemonic cultural constructs. Embodiment is thus inherently destabilizing with respect to the body, for at any time this tension can widen into a perceived disparity. ${ }^{42}$

\section{Possibilities of a Sacred Posthuman Sexuality?}

Perhaps there is the possibility of new configurations of sexual practices that can also be endowed with sacred attributes. Elaine Graham writes:

To be human is already to be in a web of relationships, where our humanity can only be articulated-iterated-in and through our environment, our tools, our artefacts, and the networks of human and nonhuman life

39. Abraham H. Maslow, "Love in Self-Actualizing People," in Manfred F. DeMartino (ed.), Sexual Behavior and Personality Characteristics (New York: The Citadel Press, 1963), p. 148.

40. Dyens, Metal and Flesh, p. 20.

41. Dyens, Metal and Flesh, p. 21.

42. N. Katherine Hayles, How We Became Posthuman: Virtual Bodies in Cybernetics, Literature, and Informatics (Chicago: University of Chicago Press, 1999), p. 197. 
around us. It also means, I think, that we do not need to be afraid of our complicity with technologies, or fear our hybridity, or assume that proper knowledge of and access to God can only come through a withdrawal from these activities of world-building. ${ }^{43}$

But what happens when the artifacts we have created allow us to project our being away from the body? Perhaps sexuality, love, and the sacred are phenomena that take place in our minds, but even then the mind is inseparable from the body. Nasio notes that love is an emotion that takes place both in our minds and in the presence of the other:

The loved one exists in two ways: on the one hand, he or she is outside us, as an individual living in the world, and on the other hand, he or she is inside us as a fantasized presence-imaginary, symbolic, and realthat regulates the imperious flux of desire and structures the order of the unconscious. Of these two presences-living and fantasized-it is the second that dominates since our behavior, most of our judgments, and all of the feelings we experience with respect to the loved one, are rigorously determined by the fantasy... We only see, hear, feel, or touch him or her while enveloped in the veil woven from the images born out of the complex fusion between his or her image and our own image. ${ }^{44}$

Thus, the adage that the brain is the most important sexual organ seems to hold true to some extent. Plato argued that writing separated that which is written from the one who knows about what was written. ${ }^{45}$ In much the same way, cyberspace separates that mind from the body that houses and shapes the mind, but the body still shapes the mind. The mediated presentation of the mind is a representation of the body as well; the text on the screen stands in synecdochically for the rest of the person.

Thus there is the possibility of presenting a mediated presence of the body. That said, the mediated body is still a pale substitute for the living, breathing body - especially when it comes to interactions of an erotic nature. This is not to say that all erotic interactions cannot be adequately accounted for in a mediated environment. One can verbally express one's love on the telephone and there is a long tradition of sending and keeping love letters. But when it comes to enacting the complete range of available sexual expression, one still must have the body present. Jean Baudrillard notes that "sex is not a function, it is what makes a body a body." ${ }^{46}$ Sex is an integral part of the body

43. Elaine Graham, "Post/Human Conditions," Theology \& Sexuality 10.2 (2004), pp. 27-28.

44. Nasio, Book of Love and Pain, p. 30.

45. Plato, "Phaedrus," in Edith Hamilton and Huntington Cairns (eds.), The Collected Dialogues of Plato, Including the Letters (Princeton, NJ: Princeton University Press, 1961), 275d, p. 521.

46. Jean Baudrillard, Simulacra and Simulation (trans. Sheila Faria Glaser; Ann Arbor: University of Michigan Press, 1994), p. 98. 
and sexual behaviour is an integral part of being in the body. Richard Zaner argues that

to be embodied is to be embodied with a certain sex, and the sexuality of the body-proper manifests itself in a variety of manners. It is, we must say, one mode in which conciousness "lives" or "exists" itself concretely. Thus, in some manner at least, sexuality "expresses" one's existence, and one's existence "expresses" his sexuality. ${ }^{47}$

Sexuality and embodiment and existence are all imbricated.

Despite the need for the body, we can and do feel something when we engage in erotic activities online. Howard Rheingold asks:

If technology enables you to experience erotic frissons or deep physical, social, emotional communion with another person with no possibility of pregnancy or sexually transmitted disease, what then of conventional morality, and what of the social rituals and cultural codes that exist solely to enforce that morality? Is disembodiment the ultimate sexual revolution and/or the first step toward abandoning our bodies? ${ }^{48}$

But one would only be able to completely abandon the body if it were possible to conflate the erotic with the sexual and to experience cyberspace on its own terms rather than as an embodied entity. In an online world, there is no real difference between you and me, at least in a physical sense. In our exchange we become a series of electrons that intermingle in the ether of cyberspace. This being the case, what is the exact difference in terms of connection and intimacy? In some regards, an online intermingling of being can be considered more intimate than that which can be had in the corporeal sense. Two or more people can become one in ways that transcend physical limitations. But all of this is only plausible on a theoretical level right now. I do not experience my being in cyberspace as a series of electrons containing me. This is a fundamental problem of embodiment, but this limitation is possible to overcome. Drawing on Lacan, Slavoj Žižek writes:

An even more "real" approach is opened up by the prospect of the direct manipulation of our neurons: although not "real" in the sense of being part of the reality in which we live, this pain is impossible-real... What we experience here at its purest is thus the gap between reality and the Real: the Real of, say, the sexual pleasure generated by direct neuronal intervention does not take place in the reality of bodily contacts, yet it is "more real than reality," more intense. ${ }^{49}$

47. Richard M. Zaner, The Problem of Embodiment: Some Contributions to a Phenomenology of the Body (The Hague: Martinus Nijhoff, 1964), p. 193.

48. Howard Rheingold, "Teledildonics," in Victor J. Vitanza (ed.), Cyberreader (Boston, MA: Allyn \& Bacon, 1999), p. 207.

49. Slavoj Žižek and Glyn Daly, Conversations with Žižek (Cambridge: Polity Press, 2004), p. 99. 


\section{But Maurice Merleau-Ponty explains that}

erotic perception is not a cogitatio which aims at a cogitatum; through one body it aims at another body, and takes place in the world, not in a consciousness. A sight has a sexual significance for me, not when I consider, even confusedly, its possible relationship to the sexual organs or to pleasurable states, but when it exists for my body, for that power always available for bringing together into an erotic situation the stimuli applied, and adapting sexual conduct to it. ${ }^{50}$

The erotic is always connected to the body.

All of this discussion of the body leads us to a fundamental question: Is the root of the sacred to be found in the body or outside of the body? Feminist theory has made considerable use of the idea of the goddess as a way to challenge patriarchal and phallocentric ideals. However, cyberfeminists have also drawn on the idea of the cyborg as a liberatory concept. In the oft quoted final line of her essay, "A Manifesto for Cyborgs," Donna Haraway writes, "Though both are bound in the spiral dance, I would rather be a cyborg than a goddess." ${ }^{51}$ But Haraway produces a false dichotomy - not only can it be a choice of "both/and" but "neither/nor" as well. Graham argues that "in an essay which celebrates the end of dualisms, Haraway still perpetuates one of her own: that of the dualism between the heaven and earth." ${ }^{52}$ Yet it is not only a question of heaven or earth -in the nexus of these two reside the human. In Haraway's attempt to remove the spiritual from the cyborg, she also, to some extent, removes the humanity from the cyborg. I suggest that it is the spiritual elements of life that not only make us human, but also make life worth living. By spiritual, I do not mean religion, although the two are often conflated. Rather, I mean a kind of transcendence, an understanding that there is a realm of existence beyond that which we experience in our daily lives. The spiritual transcends the corporeal, yet is rooted in the body. Herein lies the paradox - spiritual experiences are something one does or feels, rather than something that one thinks. The spiritual is that which is difficult to explain only with logic (cyborg) - it must be experienced (flesh).

One need not be told that the body, the sexual, and the spiritual are enmeshed; the body itself is marked with atavistic connections between the spiritual and the sexual. Camille Paglia writes:

Virginity is categorically different for the sexes. A boy becoming a man quests for experience. The penis is like eye or hand, an extension of self

50. Merleau-Ponty, Phenomenology of Perception, p. 157.

51. Donna Jeanne Haraway, Simians, Cyborgs, and Women: The Reinvention of Nature (New York: Routledge, 1991), p. 181.

52. Graham, “Cyborgs or Goddesses?," p. 428. 
reaching outward. But a girl is a sealed vessel that must be broken into by force. The female body is the prototype of all sacred spaces from cave shrine to temple and church. The womb is the veiled Holy of Holies. ${ }^{53}$

Not only the body as a whole, but also the sexual organs themselves are imbued with sacred qualities. Joanna Frueh argues that "the sacred is special, yet it is also irrational, because it is mysterious, and mystery scares as well as fascinates human beings. Erotic charge-smell, taste, touch, feel, sound, and orgasm -is part of the vagina's sacredness and 'irrationality.'" 54

The notion of the sacred, like the rest of reality, is socially constructed. As such, it is possible to reconfigure our conceptions of the sacred. That said, we always exist in relation to our material conditions. Moreover, if one is to attempt to reconfigure the sacred, he or she must wish to do so. Although the idea of abandoning the flesh and exulting in a noncorporeal existence may seem enticing, the loss of physical presence seems too high a price to pay. I would rather spend a few moments in the presence of my lover than talk to her at length on the phone. Perhaps in the social construction of the sacred, we may forget that we have always worshipped that which was either familiar or mysteriouseither those things that we can see or create, or an image of God that we cannot imagine. If we are to consider the nature of the sacred, it is clear that other humans, specifically those of the opposite gender, are both familiar and mysterious. Perhaps this is one of the reasons why the union of the sexes has, and will likely continue to be, a sacred act. Together people create the mystery of love, and despite the possibility of feeling the experience in one's mind through neurological stimulation alone, when the other is physically removed, it is just an illusion. We are social beings that still enjoy the "tribal warmth of the polis," 55 thus it is logical that our conceptions of the sacred would be rooted in our intercourse-sexual and otherwise-with others.

Elaine Graham writes: "The philosophies and practices of transhumanism exhibit a will for transcendence of the flesh as an innate and universal trait, a drive to overcome physical and material reality and strive towards omnipotence, omniscience, and immortality." ${ }^{66}$ In this article, I have suggested that to transcend the flesh entirely is to leave behind that

53. Camille Paglia, Sexual Personae: Art and Decadence from Nefertiti to Emily Dickinson (New York: Vintage Books, 1991), p. 23.

54. Joanna Frueh, “Vaginal Aesthetics," Hypatia 18.4 (2003), p. 140.

55. Edwin Black, "The Second Persona," Quarterly Journal of Speech 56.2 (1970), p. 112.

56. Elaine Graham, “'Nietzsche Gets a Modem': Transhumanism and the Technological Sublime," Literature \& Theology 16.1 (2002), p. 69. 
which is most sacred to us - our humanity. Despite the impulse to leave the body behind, such actions may, in the end, be impossible anyway. Merleau-Ponty argues:

Bodily existence which runs through me, yet does so independently of me, is only the barest raw material of a genuine presence in the world. Yet at least it provides the possibility of such presence, and establishes our first consonance with the world. I may very well take myself away from the human world and set aside human existence, but only to discover in my body the same power, this time untamed, by which I am condemned to being. ${ }^{57}$

Our views of the body, specifically as it relates to the soul, have implications for how we function sexually. Christine Purdon and Laura Holdaway write, "When people monitor and judge their sexual performance, they are not attending to what is pleasurable and enjoyable about the activity." ${ }^{58}$ Purdon and Holdaway draw on work by William Masters and Virginia Johnson that suggests taking a "spectator" role during sexual intercourse is a contributing factor to sexual dysfunction. One must be in the experience. But Masters and Johnson note that sexuality is tied up in culture and one's upbringing, with religious orthodoxy playing a large part at times in sexual dysfunction. ${ }^{59}$ Georg Feuerstein suggests that the Christian "denial or denigration of bodily experience" in which the "body - or the flesh - is regarded as the enemy of the spirit," 60 leads us to view the body as intrinsically dirty or something which one must overcome. "We distrust the body, and so we constantly watch it as if it were something separate from us. Hence we can perform sexually without being truly present in the act." ${ }^{61}$ Masters and Johnson note that

an unfortunate though understandable by-product of the cultural residual of Puritan ethic (or any other 'sex is sin' concept), the separation of sex from consideration of the total human existence has become an unwitting habit. Beyond investigation of its obligatory role in reproduction, sex is all too often studied outside of its natural context. ${ }^{62}$

Perhaps posthumanism's impulse to abandon the body is simply another manifestation of the Puritan conception of the body as something which should be avoided-even one's own body-because of its

57. Merleau-Ponty, Phenomenology of Perception, pp. 165-66.

58. Christine Purdon and Laura Holdaway, "Non-Erotic Thoughts: Content and Relation to Sexual Functioning and Sexual Satisfaction," The Journal of Sex Research 43.2 (2006), p. 154.

59. They make special connection to religious orthodoxy and vaginismus. See William H. Masters and Virginia E. Johnson, Human Sexual Inadequacy (Boston, MA: Little, Brown \& Company, 1970), pp. 254-56.

60. Feuerstein, Sacred Sexuality, p. 15.

61. Feuerstein, Sacred Sexuality, p. 16.

62. Masters and Johnson, Human Sexual Inadequacy, p. 24. 
potential to lead one into sin and thus into Hell and destruction. A case study from Masters and Johnson illustrates this point:

[Mrs A's] environmental and educational background was of strictest parental, physical, and mental control enforced in a stringent disciplinary format and founded in religious orthodoxy. She was taught that almost any physical expression might be suspect of objectionable sexual connotation. For example, she was prohibited when bathing from looking at her own breasts either directly or from reflection in the mirror for fear that unhealthy sexual thoughts might be stimulated by visual examination of her own body... Mrs A's only conception of woman's role in sexual functioning was that it was dirty and depraved without marriage and that the sanctity of marriage really only provided the male partner with an opportunity for sexual expression. For the woman, the only salvation to be gained from sexual congress was pregnancy. ${ }^{63}$

Masters and Johnson note that "with an incredible number of thoushalt-nots dominating Mrs A's environmental background, it is little wonder that she was never able to develop a healthy frame of reference for the human male in general and her husband in particular as a sexual entity." 64 The experience of Mrs A provides an extreme example of what happens when the spirit is forcefully separated from the body. But is it any wonder that certain kinds of religious orthodoxies would invite such a divide? Many Christians believe in a God that has no physical body that can fill the vast expanse of space yet dwell in one's heart. And if one's telos is to become even as he is, the believer is faced with an insurmountable paradox. Posthumanism does not remove this paradox; rather, it removes God from the equation and demands that we transcend the flesh without divine aid. The question, then, is whether it is even possible to have a conception of posthuman sexuality that also retains the sacred qualities that we currently ascribe to sexuality.

As relationships become increasingly mediated, one of the first casualties is physical immediacy, and it is this immediacy that brings us closer to the sacred. This is not to say that mediated forms of communication cannot maintain and create relationships. We can use communication media to keep in touch with loved ones and fall in love with others. However, it is the rare individual who, upon falling in love with another, wishes to maintain the physical distance and keep the relationship mediated. Continuing to develop an intellectual understanding at a distance and to the exclusion of physical proximity seems a pale substitute. Perhaps one reason for this is the perception that such knowledge can be gained more efficiently and more powerfully without the intrusion of the medium.

63. Masters and Johnson, Human Sexual Inadequacy, pp. 254-55.

64. Masters and Johnson, Human Sexual Inadequacy, p. 255. 
Perhaps at its root, our conception of the sacred represents an effort to remove mediations in all of its forms. When one has a sacred experience in which he or she communes with God, it is an experience that transcends the communication experienced in common prayer. Religious individuals speak of coming closer to God, and this seems more than simply a figure of speech. When individuals "make love" (as opposed to simply having sex or fucking) they ascribe to the act a spiritual element that transcends biological urges. Thus the biblical imperative to become one flesh is, at its heart, a command to completely remove mediation altogether. Of course, this is just as impossible as the urge to become like a disembodied deity, but it provides a way to consider the realm of the sacred. If sacred experiences lie in the removal of mediation, an increase in mediation can only lead one further from the sacred. At some point the conception of sacredness may become reconfigured; then the question will be whether we as humanity have given up something that we ought not to have. We may find that removing the spiritual in favour of mediation is to give up our birthright as human beings for a mess of pottage.

Brett Lunceford is Assistant Professor of Communication at the University of South Alabama. An earlier version of this article was presented at the 2008 convention of the Media Ecology Association in Santa Clara, California.

Department of Communication, University of South Alabama, 1000 University Commons, AL 36688; lunceford@usouthal.edu

\section{BiBLIOGRAPHY}

Anand, Margot. The Art of Sexual Magic. New York: G. P. Putnam's Sons, 1995.

Augustine. The City of God. Trans. Gerald G. Walsh, et al.; Garden City, NY: Image Books, 1958.

Baudrillard, Jean. Simulacra and Simulation. Trans. Sheila Faria Glaser; Ann Arbor: University of Michigan Press, 1994.

Black, Edwin. “The Second Persona." Quarterly Journal of Speech 56.2 (1970), pp. 11119.

Bright, Susie. Full Exposure: Opening up to Sexual Creativity and Erotic Expression. San Francisco: HarperSanFrancisco, 1999.

Butler, Judith. Bodies That Matter: On the Discursive Limits Of "Sex." New York: Routledge, 1993.

-Gender Trouble: Feminism and the Subversion of Identity. New York: Routledge, 1990.

Caputi, Jane. "The Naked Goddess: Pornography and the Sacred." Theology E Sexuality 9.1 (2002), pp. 180-200. doi:10.1177/135583580200900116

Chambers, Paul. Sex and the Paranormal: Human Sexual Encounters with the Supernatural. London: Vega, 2003.

Dibbell, Julian. "A Rape in Cyberspace." In Victor J. Vitanza (ed.), Cyberreader. Boston: Allyn \& Bacon, 1999. 
Dyens, Ollivier. Metal and Flesh: The Evolution of Man: Technology Takes Over. Cambridge, MA: MIT Press, 2001.

Feuerstein, Georg. Sacred Sexuality: Living the Vision of the Erotic Spirit. Los Angeles: Jeremy P. Tarcher, 1992.

Fortunati, Leopoldina. "The Human Body: Natural and Artificial Technology." In James Everett Katz (ed.), Machines That Become Us: The Social Context of Personal Communication Technology, pp. 71-87. New Brunswick, NJ: Transaction Publishers, 2003.

Frueh, Joanna. "Vaginal Aesthetics.” Hypatia 18.4 (2003), pp. 137-58. doi:10.2979/ HYP.2003.18.4.137

Graham, Elaine L. "Cyborgs or Goddesses? Becoming Divine in a Cyberfeminist Age." Information Communication \& Society 2.4 (1999), pp. 419-38. doi:10.1080/ 136911899359484

-Representations of the Post/Human: Monsters, Aliens, and Others in Popular Culture. New Brunswick, NJ: Rutgers University Press, 2002.

- “'Nietzsche Gets a Modem': Transhumanism and the Technological Sublime." Literature \& Theology 16.1 (2002), pp. 65-80. doi:10.1093/litthe/16.1.65

_ “Post/Human Conditions." Theology E Sexuality 10.2 (2004), pp. 10-32. doi:10.1177/ 135583580401000202

Haraway, Donna Jeanne. Simians, Cyborgs, and Women: The Reinvention of Nature. New York: Routledge, 1991.

Hayles, N. Katherine. How We Became Posthuman: Virtual Bodies in Cybernetics, Literature, and Informatics. Chicago: University of Chicago Press, 1999.

Kristeva, Julia. Tales of Love. Trans. Leon S. Roudiez; New York: Columbia University Press, 1987.

McLuhan, Marshall. Understanding Media: The Extensions of Man. Cambridge, MA: MIT Press, 1st MIT Press edn, 1994.

Maslow, Abraham H. “Love in Self-Actualizing People." In Manfred F. DeMartino (ed.), Sexual Behavior and Personality Characteristics, pp. 144-53. New York: The Citadel Press, 1963.

Masters, William H., and Virginia E. Johnson. Human Sexual Inadequacy. Boston, MA: Little, Brown \& Company, 1970.

Merleau-Ponty, Maurice. Phenomenology of Perception. Trans. Colin Smith; London: Routledge \& Kegan Paul, 1962.

Mumford, Lewis. Technics and Civilization. New York: Harcourt Brace, 1963.

Nasio, Juan-David. The Book of Love and Pain: Thinking at the Limit with Freud and Lacan. Trans. David Pettigrew and François Raffoul; Albany: State University of New York Press, 2004.

Negroponte, Nicholas. Being Digital. New York: Knopf, 1995.

Paglia, Camille. Sexual Personae: Art and Decadence from Nefertiti to Emily Dickinson. New York: Vintage Books, 1991.

Plato, "Phaedrus." In Edith Hamilton and Huntington Cairns (eds.), The Collected Dialogues of Plato, Including the Letters, pp. 475-525. Princeton, NJ: Princeton University Press, 1961.

- "Symposium." In Edith Hamilton and Huntington Cairns (eds.), The Collected Dialogues of Plato, Including the Letters, pp. 526-74. Princeton, NJ: Princeton University Press, 1961.

Purdon, Christine, and Laura Holdaway. "Non-Erotic Thoughts: Content and Relation to Sexual Functioning and Sexual Satisfaction." The Journal of Sex Research 43.2 (2006), pp. 154-62.

Rheingold, Howard. “Teledildonics.” In Victor J. Vitanza (ed.), Cyberreader, pp. 202209. Boston, MA: Allyn \& Bacon, 1999. 
Rosmini, Antonio. Development of the Human Soul. Trans. Denis Cleary and Terence Watson; Durham, UK: Rosmini House, 1999.

Sartre, Jean-Paul. Existentialism and Human Emotions. Secaucus, NJ: Citadel Press, 1957.

"Sinulate Entertainment Home Page." Sinulate Entertainment, http://www.sinulate. com.

Whitty, Monica Therese. "Cyber-Flirting: Playing at Love on the Internet." Theory $\mathcal{E}$ Psychology 13.3 (2003), pp. 339-57. doi:10.1177/0959354303013003003

Zaner, Richard M. The Problem of Embodiment: Some Contributions to a Phenomenology of the Body. The Hague: Martinus Nijhoff, 1964.

Žižek, Slavoj, and Glyn Daly. Conversations with Žižek. Cambridge: Polity Press, 2004. 